\title{
ANALISIS NORMATIF PENGATURAN PRINSIP-PRINSIP DEMOKRASI DALAM LEGISLASI PERATURAN DAERAH
}

\author{
Oleh : \\ Anis Ibrahim*
}

\begin{abstract}
Since regional autonomy is broadly implemented, the existence of Perda (local regulation) is one of the central issues and becomes unending controversies, marked by many unaspirative Perda. "Certainly, the existence of the Perda are not separated from the rules that as the base for the legislational process of the Perda. After being analyzed based on principles of democracy, it can be concluded that various regulations on from which to base the formation of Perda, some have been based on the prniciples, some have not. Those that have been based on the principles should be perfected in detail so that the legislational process of the perda works in the proper track of substantial democracy.
\end{abstract}

Kata Kunci: legislasi, perda, prinsip demokrasi

\section{PENDAHULUAN}

Demokrasi sebagai buah dari perjuangan reformasi melahirkan tatanan baru dalam lalulintas hubungan pemerintah pusat dengan pemerintah daerah. Wujud nyatanya adalah berupa otonomi daerah dan desentralisasi yang sejati yang diberikan kepada masing-masing pemerintahan daerah. Intinya adalah bahwa eksistensi otonomi dan desentralisasi itu berangkat dari pemerintah pusat. Ia merupakan akibat dari pemencaran kekuasaan secara vertikal yang terimplementasikan karena dilandaskan pada prinsip demokrasi. Dalam perspektifyang demikian, Moh. Mahfud MD menegaskan bahwa prinsip otonomi daerah dan desentralisasi dalam hubungan kekuasaan (gezagverhouding) antara pemerintah pusat dan daerah merupakan salah satu cara untuk mengimplementasikan prinsip demokrasi. ${ }^{1}$
Dilihat dari perspektif state-society relation, dapat dikatakan bahwa salah satu tujuan utama dari otonomi daerah adalah membuka akses yang lebih besar kepada masyarakat sipil (civil society) untuk berpartisipasi baik pada proses pengambilan keputusan maupun dalam pelaksanaannya. ${ }^{2}$ Dengan demikian, semangat terpenting yang terkandung dalam otonomi daerah di Indonesia, baik secara prosedural maupun substansial, ada dua, yaitu pertama, adalah pengukuhan kembali kedaulatan rakyat (demokratisasi), dan kedua, adalah guna mendorong terwujudnya tata pemerintahan yang

* Sekolah Tinggi Ilmu Hukum Jenderal Sudirman. Jl. Mahakam Nomor 7 Lumajang-Jawa Timur. E-mail: anisibrahim18@gmail.com

${ }^{1}$ Moh. Mahfud MD (1999) Pergulatan Politik dan Hukum di Indonesia. Gama Media, Yogyakarta, hal. 185.

${ }^{2}$ Syarif Hidayat (2002) Refleksi Realitas Otonomi Daerah dan Tantangan ke Depan. Pustaka Quantum, Jakarta, hal. 32. 
baik (good governance) di tingkat lokal maupun di tingkat nasional.

Salah satu idealitas dan rasionalitas yang penting dari pelaksanaan otonomi daerah adalah membuat proses kebijakan menjadi lebih dekat dengan warga dan stakeholders-nya, sehingga mereka dapat berpartisipasi dalam proses perumusan kebijakan dengan mudah dan intensif. Dengan menggeser lokus kebijakan dari pusat ke daerah diharapkan proses formulasi kebijakan menjadi (1) lebih terbuka (transparan) dan (2) partisipasi warga masyarakat dan stakeholders menjadi semakin tinggi sehingga kebijakan publik benar-benar mengabdi pada kepentingan publik dan bukan pada kepentingan elite birokrasi dan politik. $^{3}$

Terkait dengan hal tersebut, maka keberadaan Peraturan Daerah (Perda) dalam otonomi daerah sangat penting artinya, sebab Perda merupakan konsekuensi logis dari wewenang daerah untuk mengatur dan mengurus rumah tangganya sendiri. ${ }^{4}$ Dengan demikian, Perda merupakan conditio sine quanon (syarat mutlak/syarat absolut) dalam rangka melaksanakan kewenangan otonomi daerah tersebut. Ada dua hal yang terjalin antara Perda dengan otonomi daerah, yaitu: (1) Perda harus dijadikan pedoman bagi daerah otonom dalam melaksanakan semua urusan-urusan daerah, dan (2) Perda juga harus dapat memberikan perlindungan hukum bagi rakyat daerah.

Namun, sejak otonomi daerah yang luas diimplementasikan, eksistensi Perda sebagai salah satu sarana legal atas kebijakan daerah merupakan salah satu isu sentral dan menjadi kontroversi yang hingga kini belum berakhir. Telah berkali-kali Pemerintah Pusat mempublikasikan adanya Perda yang dianggap tidak mampu mewadahi kepentingan nasional, konteks sosial setempat, bertentangan dengan peraturan perundang-undangan yang lebih tinggi dan, kepentingan umum, serta yang menurut banyak kalangan dinilai tidak aspiratif baik dari dimensi publik maupun dunia usaha, sehingga direkomendasikan untuk dibatalkan dan/atau direvisi. Perda demikian ini kemudian populer dengan sebutan "Perda bermasalah" atau "Perda tidak aspiratif".

\footnotetext{
${ }^{3}$ Agus Dwiyanto (2002) Reformasi Tata Pemerintahan dan Otonomi Daerah, Ringkasan Eksekutif. Pusat Studi Hukum dan Kebijakan Universitas Gadjah Mada, Yogyakarta, hal. 17.

${ }^{4}$ Buchari Zaenun (1990) Administrasi dan Manajemen Pemerintah Negara Indonesia Menurut Undang-Undang Dasar 1945. Haji Masagung, Jakarta, hal. 5.
}

Beranjak dari uraian singkat tersebut di atas maka tidak berlebihan jika muncul suatu pemahaman bahwa Perda tidak aspiratif dan tidak demokratis barang tentu tidak muncul secara tiba-tiba. Kemunculannya tidak bisa dilepaskan dari latar belakang yang mendahuluinya, yakni pada saat Perda dibentuk melalui proses legislasi ${ }^{5}$ yang dilakukan oleh pemerintah daerah dan Dewan Perwakilan Rakyat Daerah (DPRD) di masing-masing daerah. Persoalan proses pembentukan Perda yang tidak demokratis tersebut barang tentu harus juga dilacak dari aturan hukum yang mendasari legislasinya, yang dalam hal ini dapat dilacak baik melalui Undang-Undang tentang Pembentukan Peraturan Perundang-Undangan (UUP3 2004) sebagimana termuat dalam UU No. 10 Tahun 2004 dan perubahannya sebagaimana yang ada dalam UU No. 12 Tahun 2011 (UUP3 2011), UU No. 32 Tahun 2004 tentang Pemerintahan Daerah (UU Pemda 2004), dan peraturan perundang-undangan dibawahnya.

Penelitian tentang bagaimana pengaturan prinsip-prinsip dasar demokrasi dalam legislasi Perda menjadi penting sebab dengan melalui aturan itulah proses legislasi daerah merupakan proses yang legal, jelas prosedurnya dan adil. Jika tidak ada sandaran hukumnya, maka proses legislasi berada dalam kondisi yang tak menentu, tidak jelas batasbatasnya, tidak konsisten, dan bisa jadi prinsipprinsip demokrasi dalam legislasi Perda dapat terabaikan. Dengan demikian maka menjadi urgen untuk melakukan penelitian dengan tema yang sekaligus menjadi judul penelitian ini yakni:Analisis Normatif Pengaturan Prinsip-Prinsip Demokrasi Dalam Legislasi Peraturan Daerah.

\section{Rumusan Masalah}

Berdasarkan uraian seperti yang terpapar dalam Latar Belakang di atas, maka penelitian ini berangkat 1 (satu) pertanyaan dasar yang sekaligus merupakan permasalahan pokok studi yang dirumuskan sebagai berikut: "bagaimanakah pengaturan tentang prinsipprinsip demokrasi dalam legislasi Peraturan Daerah?"

${ }^{5} \mathrm{Al}$. Andang L. Binawan menyatakan bahwa legislasi, seperti halnya banyak kata serapan yang berakhiran 'asi', menunjuk pada suatu proses, untuk menghasilkan hukum (dalam arti perundang-undangan). Lihat Al. Andang L. Binawan (2005) "Merunut Logika Legislasi". Jentera Jurnal Hukum. Edisi 10 Tahun III, Oktober 2005, hal. 9. 


\section{Tujuan Penelitian}

Berdasarkan rumusan permasalahan penelitian tersebut di atas, maka tujuan dari penelitian ini adalah untuk mendeskripsikan sekaligus menganalisis berbagai peraturan perundang-undangan yang mengatur tentang legislasi Perda berdasarkan perspektif prinsip-prinsip demokrasi. Dengan demikian penelitian ini akan dapat menjawab apakah perumusan aturan legislasi Perda yang ada dalam berbagai peraturan perundang-undangan (UUP3 2004, UUP3 2011, UU Pemda 2004, dan sebagainya) sudahkah sesuai ataukah belum dengan prinsipprinsip demokrasi.

\section{Metode Penelitian}

Tipe penelitian hukum ini adalah penelitian yuridis normatif yaitu suatu tipe penelitian yang digunakan untuk mengkaji/menganalisis/membahas berlakunya kaidah-kaidah seperti berlakunya peraturan perundang-undangan dalam hukum positif yang berhubungan dengan permasalahan yang diajukan dan dianalisis dalam penelitian ini. Isu utama dalam penelitian ini adalah tentang rumusan normatif pengaturan legislasi Perda dalam kaitannya dengan prinsip-prinsip demokrasi. Sedangkan pendekatan masalah yang digunakan dalam penelitian hukum ini adalah pendekatan peraturan perundang-undangan (statute approach) dan pendekatan konseptual (conceptual approach).

Dalam penelitian hukum dengan tipe yuridisnormatifini, bahan-bahan hukum dalam penelitian hukum ini terdiri atas: $a$. bahan hukum primer, $b$. bahan hukum skunder, dan c. bahan hukum tertier. Sebelum melakukan analisis, maka dilakukan langkah-langkah yang sistematis dalam penelitian hukum ini, yaitu (a) pengidentifikasian fakta hukum dan mengeliminasi hal-hal yang tidak relevan dalam hal penetapan isu hukum yang hendak dibahas; (b) pengumpulan bahan-bahan hukum yang sekiranya dipandang mempunyai relevansi dengan bahanbahan non hukum; (c) penelaahan atas isu hukum yang diajukan berdasarkan bahan-bahan hukum yang dikumpulkan; (d) penarikan simpulan berdasarkan argumentasi yang menjawab isu hukum; dan (e) pemberian preskripsi berdasarkan argumentasi yang telah dibangun dalam simpulan.

Bahan hukum yang terkumpul kemudian disusun secara sistematis dan terarah, selanjutnya dianalisis dengan metode deskriptif kualitatif. Dalam hal ini yang dinanalisis dengan menggunakan prinsip-prinsip demokrasi adalah UUP3 2004, UUP3 2011, UU Pemda 2004, PP No. 16/2010, Permendagri Nomor 16/2006, dan Keputusan DPRD Kabupaten Lumajang No. 04 Tahun 2010 tentang Peraturan Tata Tertib Dewan Perwakilan Rakyat Daerah Kabupaten Lumajang. Sedangkan metode yang digunakan untukmenarik simpulan adalah metode deduktif.

\section{Hasil Penelitian Dan Pembahasan}

\section{Legislasi Peraturan Daerah Menurut Undang- Undang Nomor 10 Tahun 2004 tentang Pem- bentukan Peraturan Perundang-Undangan}

Ketentuan hukum yang mengatur tentang Perda dan proses pembentukannya menurut UUP3 2004 diatur dalam Pasal 7, Pasal 12, Pasal 15, Pasal 26Pasal 31, Pasal 40-Pasal 43, Pasal 45, Pasal 52 dan Pasal 53. Dengan menggunakan rumusan Pasal 1 angka 1, dapt dikonstatasi bahwa legislasi Perda adalah suatu proses pembuatan Perda yang pada dasarnya dimulai dari perencanaan, persiapan, teknik penyusunan, perumusan, pembahasan, pengesahan, pengundangan, dan penyebarluasan. Menurut Pasal 12, "Materi muatan Perda adalah seluruh materi muatan dalam rangka penyelenggaraan otonomi daerah dan tugas pembentuan, dan menampung kondisi khusus daerah serta penjabaran lebih lanjut peraturan perundang-undangan yang lebih tinggi".

UUP3 2004 ini juga dirumuskan tentang asasasas asas Pembentukan Peraturan Perundangundangan yang baik sebagaimana diatur dalam Pasal 5. Salah satu asas yang terkait dengan demokratisasi dalam legislasi Perda adalah asas keterbukaan sebagaimana diatur pada Hurufg dari Pasal 5 tersebut yang berbunyi: Dalam membentuk Peraturan Perundang-undangan harus dilakukan berdasarkan pada asas Pembentukan Peraturan Perundangundangan yang baik, yang meliputi:a....., b, ....., g. keterbukaan". Dalam penjelasannya disebutkan bahwa" 
Berdasarkan uraian singkat tersebut dapat disimpulkan bahwa UUP3 2004 telah merumuskan beberapa prinsip dasar utama dalam legislasi Perda. Bahkan dalam Pasal 5 hurufg dikonstantasi tentang rumusan asas "keterbukaan" dalam legislasi Perda. Dalam penjelasan disebutkan bahwa "Yang dimaksud dengan "asas keterbukaan" adalah bahwa dalam Pembentukan Peraturan Perundang-undangan mulai dari perencanaan, penyusunan, pembahasan, pengesahan atau penetapan, dan pengundangan bersifat transparan dan terbuka. Dengan demikian, seluruh lapisan masyarakat mempunyai kesempatan yang seluas-luasnya untuk memberikan masukan dalam Pembentukan Peraturan Perundang-undangan".

Asas ini kemudian diderivasi langsung melalui pasal-pasal di bawahnya yaitu dengan dirumuskannya 2 (dua) prinsip dasar demokrasi, yakni norma tentang penyebarluasan draf Raperda dan norma partisipasi publik dalam legislasi Perda dalam UUP3 2004. Penyebarluasan draf Raperda tersebut dirumuskan pada Pasal 30 UUP3 2004 yang berbunyi:

(1) Penyebarluasan rancangan peraturan daerah yang berasal dari dewan perwakilan rakyat daerah dilaksanakan oleh sekretariat dewan perwakilan rakyat daerah.

(2) Penyebarluasan rancangan peraturan daerah yang berasal dari gubernur atau bupati/walikota dilaksanakan olah sekretaris daerah.

Tidak hanya mengatur masalah penyebarluasan darfRaperda secara institusional, UUP3 2004 juga merumuskan tentang media tempat penyebarluasan Raperda, misalnya melalui Televisi Republik Indonesia, Radio Republik Indonesia, Internet, media cetak seperti surat kabar, majalah, dan edaran di daerah yang bersangkutan. Secara normatif tujuan dari penyebarluasan Raperda adalah agar khalayak ramai (masyarakat) mengetahui adanya rancangan peraturan daerah yang sedang dibahas di dewan perwakilan rakyat daerah yang bersangkutan. Dengan demikian masyarakat dapat memberikan masukan atas materi rancangan peraturan daerah yang sedang dibahas tersebut (Penjelasan Pasal 30).

Namun demikian dapat dikemukakan bahwa rumusan norma dalam Pasal 30 tersebut sifatnya kurang imperatif, dalam arti bahwa penyebarluasan Raperda itu merupakan keharusan atukah bukan keharusan, tidak ada rumusannya tentang hal itu.
Dengan rumusan "dilaksanakan oleh sekretaris ..." tanpa ada kata "harus" yang mendahului frasa "dilaksanakan oleh sekretaris ...." menunjukkan bahwa perihal penyebarluasan Raperda memang bukan suatu keharusan. Jadi jika sekretaris daerah atau pun sekretaris DPRD tidak melakukan penyebarluasan Raperda baik pada saat tengah disusun maupun pada waktu dibahas bersama, maka tidak ada sanksi apapun bagi mereka.

Dalam UUP3 2004 memang tidak ada satu ketentuan pun yang bisa dijadikan sarana hukum yang memaksa lembaga pembentuk Perda untuk menyebarluaskan Raperda. Demikian juga makala Raperda tidak disebarluaskan tidak mempengaruhi legalitas yuridis dari Raperda yang telah memperoleh persetujuan bersama dan disahkan menjadi Perda.

Sementara itu, prinsip partisipasi publik (masyarakat) dalam pembentukan Perda juga telah diatur dalam UUP3 2004, yakni dirumuskan pada Pasal 53 yang berbunyi bahwa "Masyarakat berhak memberikan masukan secara lisan atau tertulis dalam rangka penyiapan atau pernbahasan rancangan undang-undang dan rancangan peraturan daerah". Selanjutnya dalam penjelasan Pasal 53 disebutkan bahwa "Hak masyarakat dalam ketentuan ini dilaksanakan sesuai dengan Peraturan Tata Tertib Dewan Perwakilan Rakyat/dewan, perwakilan rakyat daerah".

Dengan rumusan yang demikian itu maka dapat dikemukakan bahwa hak masyarakat untuk berpartisipasi dalam legislasi Perda itu selanjutnya akan dirumuskan dalam Peraturan Tatib DPRD. Jadi, bagaimana masyarakat akan melaksanakan partisipasi serta dalam tahapan apa saja dapat melakukan partisipasi, bagaimana mekanisme partisipasi dan sebagaimanya tergantung aturan dalam Tatib DPRD.

Terkait dengan rumusan normatif hak masyarakat dalam Pasal 53 tersebut Saldi Isra mengomentari bahwa hak masyarakat demikian ini sebagai ketentuan yang "relatif', sebab masih tergantung pada aturan yang dibuat oleh DPRD dalam kerangka menjamin pelaksanaan hak masyarakat untuk berpartisipasi dalam pembentukan Perda. ${ }^{6}$ Jadi pada akhirnya pengakuan, penghormatan, dan penerapan hak masyarakat dalam legislasi Perda tergantung DPRD.

${ }^{6}$ Saldi Isra (2004) "Agenda Pembaruan Hukum: Catatan Fungsi Legislasi DPR". Jentera Jurnal Hukum. Edisi 3-Tahun II, November 2004, hal. 71-72. 
Legislasi Peraturan Daerah Menurut UndangUndang Nomor 32 Tahun 2004 tentang Pemerintahan Daerah

Ketentuan hukum yang mengatur tentang Perda dan proses pembentukannya menurut UU Pemda 2004 diatur dalam Pasal 41, Pasal 42, Pasal 44, Pasal 136 -Pasal 149, dan Penjelasan. Pengaturan tentang legislasi Perda dalam UU ini sedikit berbeda ada yang tetap, ada yang dihilangkan, dan ada yang ditambahi dibanding dengan ketentuan legislasi Perda dalam UUP3. Di samping tidak mengatur tentang Prolegda dan sosialisasi Perda, UU Pemda 2004 menambah ketentuan baru yang berupa kewajiban daerah untuk menyampaikan Raperda yang telah disetujui bersama kepada pemerintah pusat untuk diklarifikasi dan dievaluasi.

Sebelum mengatur tentang prosedur legislasi Perda, dalam UU Pemda 2004 ini juga diatur di dalamnya tentang asas-asas legislasi Perda yang baik. Pasal 137 hurufg menentukan bahwa Perda dibentuk berdasarkan pada asas pembentukan perundang-undangan yang baik yang salah satu asasnya adalah "asas keterbukaan". Dalam penjelasan disebutkan: "Cukup jelas"

Berdasarkan uraian singkat tersebut dapat disimpulkan bahwa UUP3 2004 telah merumuskan asas keterbukaan dalam legislasi Perda yang kemudian dijabarkan lebih lanjut dengan munculya 2 (dua) rumusan prinsip dasar demokrasi, yakni norma tentang penyebarluasan draf Raperda dan partisipasi publik dalam legislasi Perda. Asas keterbukaan dirumuskan dalam Pasal 137 huruf g UU Pemda 2004. Asas keterbukaan ini merupakan salah satu asas yang menjadi dasar pembentukan Perda yang baik. Perumusan asas demikian ini tidak lebih sebagai pengulangan yang ada dalam Pasal 5 hurufg UUP3 2004. Hanya saja apa yang dimaksud dengan asas keterbukaan tersebut tidak ada penjelasannya, sebab dalam Penjelasan disebutkan "Sudah jelas".

Terkait dengan penyebarluasan drafRaperda, UUPemda 2004 mengaturnya pada Pasal 142 yang bunyi selengkapnya adalah sebagai berikut:

(1) Penyebarluasan rancangan Perda yang berasal dari DPRD dilaksanakan oleh sekretariat DPRD.

(2) Penyebarluasan rancangan Perda yang berasal dari Gubernur, atau Bupati/Walikota dilaksanakan oleh sekretariat daerah.
Norma penyebarluasan Raperda sebagai kokretisasi dari asas keterbukaan tersebut rumusannya mirip dengan rumusan Pasal 30 UUP3 2004 yang berbunyi:

(1) Penyebarluasan rancangan peraturan daerah yang berasal dari dewan perwakilan rakyat daerah dilaksanakan oleh sekretariat dewan perwakilan rakyat daerah.

(3) Penyebarluasan rancangan peraturan daerah yang berasal dari gubernur atau bupati/walikota dilaksanakan olah sekretaris daerah.

Tidak seperti UUP3 2004, rupanya UU Pemda 2004 tidak mengatur masalah tentang media tempat penyebarluasan Raperda. Dalam Penjelasan dikatakan "Cukup jelas". Ketiadaan penjelasan ini barangkali dikarenakan UU Pemda 2004 bukan merupakan lex specialis tentang legislasi Perda. Sehingga dapatlah dipahami bahwa UU Pemda ini tidak memberikan penjelasan yang lebih rinci jika dibanding dengan UUP3 2004 yang memang dimaksudkan untuk menjadi pedoman legislasi peraturan perundang-undangan.

Sebagaimana halnya dengan UUP3 2004, rumusan norma dalam Pasal 142 tersebut sifatnya kurang imperatif, dalam arti bahwa penyebarluasan Raperda itu merupakan keharusan atukah bukan keharusan, tidak ada rumusannya tentang hal itu. Dengan rumusan "dilaksanakan oleh sekretaris ..." tanpa ada kata "harus" yang mendahului frasa "dilaksanakan oleh sekretaris ...." menunjukkan bahwa perihal penyebarluasan Raperda memang bukan suatu keharusan. Jadi jika sekretaris daerah atau pun sekretaris DPRD tidak melakukan penyebarluasan Raperda baik pada saat tengah disusun maupun pada waktu dibahas bersama, maka tidak ada sanksi apapun bagi mereka.

Demikian juga seperti yang diatur dalam UUP3 2004, UU dalam Pemda 2004 tidak ada satu ketentuan pun yang bisa dijadikan sarana hukum yang memaksa lembaga pembentuk Perda untuk menyebarluaskan Raperda. Demikian juga makala Raperda tidak disebarluaskan tidak mempengaruhi legalitas yuridis dari Raperda yang telah memperoleh persetujuan bersama dan disahkan menjadi Perda.

Sementara itu, prinsip partisipasi publik (masyarakat) dalam pembentukan Perda diatur dalam Pasal 139 ayat (1) UU Pemda yang berbunyi: 
"Masyarakat berhak memberikan masukan secara lisan atau tertulis dalam rangka penyiapan atau pembahasan rancangan Perda". Dalam Penjelasannya dirumuskan bahwa: "Hak masyarakat dalam ketentuan ini dilaksanakan sesuai dengan Peraturan Tata Tertib DPRD". Rumusan yang demikian ini persis sama dengan rumusan yang ada dalam UUP3 2004 Pasal 53 yang berbunyi bahwa "Masyarakat berhak memberikan masukan secara lisan atau tertulis dalam rangka penyiapan atau pernbahasan rancangan undang-undang dan rancangan peraturan daerah". Selanjutnya dalam penjelasan Pasal 53 disebutkan bahwa "Hak masyarakat dalam ketentuan ini dilaksanakan sesuai dengan Peraturan Tata Tertib Dewan Perwakilan Rakyat/dewan, perwakilan rakyat daerah".

Sebagaimana yang tersebut dalam UUP3 2004, dengan rumusan hak masyarakat dalam UU Pemda 2004 yang demikian itu maka dapat dikemukakan bahwa hak masyarakat untuk berpartisipasi dalam legislasi Perda itu selanjutnya akan dirumuskan dalam Peraturan Tatib DPRD. Jadi, bagaimana masyarakat akan melaksanakan partisipasi serta dalam tahapan apa saja dapat melakukan partisipasi, bagaimana mekanisme partisipasi dan sebagaimanya tergantung aturan dalam Tatib DPRD.

Perumusan normatif hak masyarakat dalam legislasi Perda sebagaimana yang ada dalam Pasal 139 tersebut dapatlah dikatakan sebagai ketentuan yang "relatif", sebab masih tergantung pada aturan yang dibuat oleh DPRD dalam kerangka menjamin pelaksanaan hak masyarakat untuk berpartisipasi dalam pembentukan Perda. Jadi pada akhirnya pengakuan dan penghormatan hak masyarakat dalam legislasi Perda tergantung DPRD.

\section{Legislasi Peraturan Daerah Menurut Peraturan Menteri Dalam Negeri Nomor 16 Tahun 2006 tentang Prosedur Penyusunan Produk Hukum Daerah}

Permendagri No. 16 Tahun 2006 tentang Prosedur Penyusunan Produk Hukum Daerah adalah pengganti dari Keputusan Menteri Dalam Negeri dan Otonomi Daerah No. 23 Tahun 2001 tentang Prosedur Penyusunan Produk Hukum Daerah yang dianggap tidak sesuai lagi akibat dari berlakunya UUP3. 2004. Penerbitan Permendagri No. 16 Tahun 2006 adalah dalam rangka tertib administrasi penyusunan produk hukum daerah. Perda sebagai salah satu jenis produk hukum daerah yang bersifat pengaturan dalam proses pembentukannya tentu berpedoman pada Kepmendagri tersebut.

Permendagri No. 16 Tahun 2006 yang ditetapkan pada tanggal 19 Mei 2006 dan terdiri atas 25 Pasal tersebut merupakan sebuah produk hukum pemerintah pusat yang di dalamnya berisi petunjuk teknis administratif tentang bagaimana pihak eksekutif daerah ketika menyiapkan dan penyusun Raperda. Kehadiran Permendagri tersebut tampaknya tidak sesuai dengan UUP3 dan UU No. 32 Tahun 2004, sebab kedua UU tersebut mengamanatkan bahwa tata cara pemerintah daerah dalam mempersiapakan Raperda akan diatur lewat peraturan presiden (Perpres). Namun, karena hingga kini Perpres dimaksud belum juga terbit, maka muncullah Pemendagri No. 16 tahun 2006 beserta Permendagri lainnya terkait dengan produk hukum daerah, seperti Permendagri No. 15 Tahun 2006 tentang Jenis dan Bentuk Produk Hukum Daerah dan Permendagri No. 17 Tahun 2006 tentang Lembaran Daerah dan Berita daerah sebagai acuan teknis yuridis-administratif bagi pemerintah daerah dalam penyiapan dan penyusunan Perda.

Prosedur penyusunan Perda menurut Permendagri No. 16 tahun 2006 adalah meliputi tahapantahapan: 1) Perencanaan (melalui Prolegda), 2) Penyusunan (oleh pimpinan satuan kerja perangkat daerah/SKPD atau didelegasikan kepada Bagian Hukum), 3) pembahasan di internal pemda (Tim Antar SKPD), 4) paraf koordinasi, 5) dikaji oleh sekretaris daerah, 6) disampaikan ke DPRD, 7) dibahas bersama oleh kepala daerah dan DPRD, 8) ditetapkan oleh kepala daerah, 9) diundangkan dalam lembaran daerah, 10) penggandaan, pendistribusian, dan pendokumentasian, dan 11) sosialisasi.

Permendagri No. 16 Tahun 2006 ini di dalamnya sama sekali tidak merumuskan ketentuan yang menyangkut prinsip-prinsip demokrasi dalam legislasi Perda. Dengan demikian, dalam Permendagri ini tidak akan diketemukan adanya rumusan tentang asas keterbukaan, prinsip penyebarluasan Raperda maupun prinsip partisipasi masyarakat pada saat Raperda sedang disiapkan.

Ketentuan penyebarluasan ini baru diatur setelah setelah Raperda disahkan/ditetapkan dan dimuat 
dalam lembaran daerah. Hal ini diatur dalam Pasal 20 ayat (1) yang berbunyi: "Produk hukum sebagaimana dimaksud dalam Pasal 15 dan Pasal 16 sebelum disebarluaskan harus terlebih dahulu dilakukan autentifikasi". Rumusan Pasal 20 ayat (1) ini bukan merupakan rumusan prinsip demokrasi, sebab yang disebarluaskan adalah Perda yang sudah jadi dan masyarakat di-fait accomply yakni tinggal menerima dan mentaati Perda yang sudah disahkan tersebut.

Bisajadi tidak dirumuskannya prinsip demokrasi dalam Peremndagri 16/2006 tersebut karena fungsi dari Permendagri adalah sebagai pedoman teknis administratif dalam pembentukan Perda di tingkat pemerintah daerah. Sehingga di dalamnya hanya diatur masalah-masalah tahapan-tahapan dan tatacara penyiapan Raperda sampai penyebarluasan setelah Raperda disahkan menjadi Perda.

Legislasi Peraturan Daerah menurut Peraturan Pemerintah Nomor 16 Tahun 2010 tentang Pedoman Penyusunan Peraturan Dewan Perwakilan Daerah tentang Tata Tertib Dewan Perwakilan Rakyat Daerah

Peraturan Pemerintah Nomor 16 Tahun 2010 tentang Pedoman Penyusunan Peraturan Dewan Perwakilan Daerah tentang Tata Tertib Dewan Perwakilan Rakyat Daerah (PP No.16/2010) merupakan pengganti dari PP No. 53/2005 tentang Perubahan PP No. 25.2004 tentang Pedoman Penyusunan Peraturan Tata Tertib Dewan Perwakilan Rakyat Daerah. Kedua PP terakhir tersebut dinyatakan sudah tidak sesuai lagi sehingga perlu diganti yakni dengan diterbitkannya PP No. 16/2010 yang diundangkan pada tanggal 28 Januari 2010.

Berdasarkan pembacaan atas seluruh norma terkait dengan legislasi Perda dapat diketengahkan bahwa dalam PP No. 16/2010 tidak terdapat materi muatan tentang prinsip-prinsip demokrasi dalam legislasi Perda. Dengan demikian dapat dilihat bahwa pada semua tingkat pembicaraan baik tingkat 1 maupun tingkat 2 tidak ada suatu ketentuan bagi DPRD untuk mempublikasikan dan mengikutsertakan masyarakat dalam pembahasan Raperda. Baru dalam Pasal 116 "Bab XV Penerimaan Pengaduan Dan Penyaluran Aspirasi Masyarakat" secara umum terdapat ketentuan yang mengatur tentang penyampaian aspirasi masyarakat. Namun ketentuan ini sifatnya umum yakni tidak hanya menyangkut masalah pembahasan Raperda tetapi juga menyangkut hal-hal di luar pembahasan Raperda.

Dengan tidak dirumuskannya perihal prinsip demokrasi dalam legislasi Perda di dalam PP No. 16/2010 bisa dikemukkan bahwa PP ini tidak cukup komprehensif dalam mengatur masalah legislasi Perda. Seharusnya PP sebagai ketentuan hukum yang lebih konkrit dibandingkan dengan UU dan sekaligus PP No. 16/2010 berkedudukan sebagai "pedoman" bagi DPRD dalam pembentukan Perda, maka di dalamnya meniscayakan aturan yang lebih rinci dan mengikat sehingga PP tersebut bisa memberikan kepastian dalam hal pembentukan Perda terutama kepastian tentang demokratisasi dalam pembentukan Perda.

Jika demikian halnya, maka ketiadaan rumusan hukum dalam PP No. 16/2010 tersebut sebagai dasar pelaksanaan prinsip demokrasi dalam legislasi Perda justru berseberangan dengan bunyi Penjelasan Umum PP itu senidir yang menyebutkan demikian: "Dalam kapasitasnya, DPRD sebagai penyelenggara pemerintahan daerah mempunyai kedudukan yang sama dengan pemerintah daerah dalam membangun dan mengusahakan dukungan dalam penetapan kebijakan pemerintahan pemerintahan daerah, yang dapat menampung dan menyalurkan aspirasi masyarakat sehingga kebijakan dimaksud dapat diterima oleh masyarakat luas".

Legislasi Peraturan Daerah Menurut Keputusan DPRD Kabupaten Lumajang No. 04 Tahun 2010 tentang Peraturan Tata Tertib Dewan Perwakilan Rakyat Daerah Kabupaten Lumajang

Untuk keseragaman dalam perumusan Tatib DPRD, pada tahun 2010 Pemerintah menerbitkan PP No. 16/2010 tentang Pedoman Penyusunan Peraturan Dewan Perwakilan Daerah tentang Tata Tertib Dewan Perwakilan Rakyat Daerah. Meski dalam semua Tatib DPRD pada dasarnya persis sama dengan yang ada dalam PP No. 16/2010, namun dalam Tatib DPRD Kabupaten Lumajang ada tambahan 1 ayat yang menjadikannya agak berbeda dengan PP No. 16/2010.

Pasal 110 ayat (8) Tatib DPRD Kabupaten Lumajang merumuskan bahwa Perda yang dibentuk tidak boleh bertentangan dengan kepentingan umum, peraturan perundang-undangan yang lebih tinggi dan peraturan daerah lainnya. Sementara Peraturan Tatib 
DPRD lainnya tidak mengatur dan merumuskan tentang larangan demikian ini. Ada pun rumusan pasal dan ayat lainnya sama sekali tidak ada perbedaan yakni kesemuanya tampak sebagai turunan dan merupakan copy paste dari PP No. 16/2010.

Dari ketentuan dalam Tatib DPRD Kabupaten Lumajang dapat diketengahkan bahwa rumusan terkait dua prinsip dasar dalam demokrasi dalam Tatib DPRD (termasuk juga dalam PP No. 16/ 2010) mengalami kemunduran manakala dibanding dengan ketentuan yang ada dalam UU No. 10/2004 tentang P3 maupun UU No. 32/2004 tentang Pemerintahan Daerah. Padahal kedua UU tersebut telah menentukan tentang tata cara penyebarluasan Raperda dan hak masyarakat untuk berpartisipasi dalam legislasi Perda termasuk rambu-rambu agar Perda tidak bertentangan dengan kepentingan umum (berarti harus melakukan konsultasi publik) dan peraturan yang lebih tinggi yang hanya diatur dalam Tatib DPRD Kabupaten Lumajang agar diatur lebih lanjut dalam Peraturan Tatib DPRD. Jadi, secara umum dapat dikatakan bahwa pada tataran normatif jaminan hukum terhadap demokratisasi dalam legislasi Perda menjadi terdegradasi dalam PP maupun Tatib DPRD Kabupaten Lumajang.

Barang tentu tidak dirumuskannya prinsip demokrasi (prinsip penyebarluasan Raperda/prinsip keterbukaan) dan prinsip partisipasi publik dalam proses legislasi Perda dalam Peraturan Tatib DPRD Kabupaten Lumajang dikarenakan Peraturan Tatib DPRD tersebut adalah sekedar penerusan dari PP No. 10/2010. Sementara PP No. 16/2010 yang dijadikan acuan dalam perumusan Tatib DPRD sama sekali tidak merumuskan prinsip-prinsip demokrasi dalam legislasi Perda di dalamya. Sehingga sangat mungkin cara merumuskannya adalah tinggal copy paste dari peraturan di atasnya sehingga kurang tajam dalam merumuskan prinsip-prinsip demokrasi dalam Peraturan Tatib DPRD Kabupaten Lumajang.

\section{Legislasi Peraturan Daerah menurut Undang- Undang Nomor 12 Tahun 2011 tentang Pem- bentukan Peraturan Perundang-undangan}

UUP3 2011 ini merupakan perubahan dari UUP3 2004, karena UUP3 2004 sudah tidak sesuai dengan perubahan zaman dan perkembangan kebutuhan masyarakat. Dalam Konsideran huruf c dinyatakanan "bahwa dalam Undang-Undang
Nomor 10 Tahun 2004 tentang Pembentukan Peraturan Perundang-undangan masih terdapat kekurangan dan belum dapat menampung perkembangan kebutuhan masyarakat mengenai aturan pembentukan peraturan perundangundangan yang baik sehingga perlu diganti”.

Terkait asas-asas pembentukan peraturan perundang-undangan yang baik, pada dasarnya ketentuan dalam UUP3 2011 ini tidak ada perubahan jika dibanding dengan yang ada dalam UUP3 2004. Seperti UUP3 2004, Pasal 5 UUP3 2011 mencantumkan tentang asas-asas pembentukan peraturan perundang-undangan yang sebanyak 7 asas yang salah satunya yakni hurufg menentukan asas keterbukaan. Dalam penjelasan hurufg disebutkan bahwa:
Huruf g:
Yang dimaksud dengan "asas keterbukaan" adalah bahwa dalam Pembentukan Peraturan Perundang-undangan mulai dari perencanaan, penyusunan, pembahasan, pengesahan atau penetapan, dan pengundangan bersifat trans- paran dan terbuka. Dengan demikian, seluruh lapisan masyarakat mempunyai kesempatan yang șeluas-luasnya untuk memberikan masukan dalam Pembentukan Peraturan Perundang- undangan.

Berdasarkan pembacaan rumusan ketentuan dalam UUP3 2011 dapat diketengahkan bahwa memang perumusan prinsip demokrasi dalam legislasi Perda lebih memberi kepastian dan kejelasan dibanding dengan UUP3 2004. Hal ini tampak, di samping adanya asas keterbukan sebagai salah satu asas dalam legislasi Perda, bahwa keniscayaan adanya Prolegda dan keniscayaan adanya Naskah Akademik sebelum dilakukan pembahasan Raperda sudah mulai tampak berseminya prinsip-prinsip demokrasi dalam legislasi Perda di tahap yang paling awal.

Menurut Pasal 92 dan Pasal 93, Prolegda niscaya disebarluaskan ke tengah-tengah masyarakat. Penjelasan Pasal 92 ayat (1) menentukan bahwa:

\footnotetext{
Yang dimaksud dengan "penyebarluasan" adalah kegiatan menyampaikan informasi kepada massyarakat mengenai Prolegda, Rancangan Peraturan Daerah Provinsi, atau Rancangan Peraturan Daerah Kabupaten/Kota yang sedang disusun, dibahas, dan yang telah diundangkan agar masyarakat dapat memberikan masukan atau tanggapan terhadap Peraturan Daerah tersebut atau memahami Peraturan Daerah Provinsi atau Peraturan Daerah Kabupaten/Kota yang telah diundangkan. Penyebarluasan Peraturan Perundang-undangan tersebut dilakukan, misalnya, melalui media elektronik dan/atau media cetak.
} 
Hak masyarakat dalam legislasi Perda juga semakin dirinci sehingga menjadi jelas siapa saja masyarakat dimaksud dan bagaimana caranya mengartikulasikan hak masyarakat dalam legislasi Perda. Tentang hal ini diatur dalam Pasal 96 dari ayat (1) hingga ayat (4). Hak masyarakat ini wujudnya adalah berupa pemberian masukan baik secara lisan maupun tulisan yang bisa dilakukan melalui a. rapat dengar pendapat umum; b. kunjungan kerja; c. sosialisasi; dan/atau d. seminar, lokakarya, dan/atau diskusi. Sementara cakupan kelompok orang, dalam penjelasan Pasal 96 ayat (3) disebutkan bahwa "Termasuk dalam kelompok orang antara lain, kelompok/organisasi masyarakat, kelompok profesi, lembaga swadaya masyarakat, dan masyarakat adat".

Meski perumusan prinsip demokrasi dalam UUP3 2011 lebih baik jika dibanding dengan UUP sebelumnya, namun bukan berarti telah sempurna. Beberapa hal yang kurang tajam dalam perumusan prinsip demokrasi dalam legislasi Perda ini dalam hal belum dirumuskannya kesetimbangan antara hak masyarakat dan kewajiban DPRD dan Pemerintah Daerah terkait dengan kesungguhan mereka untuk mengagregasikan dan mengakomodasikan masukanmasukan dari masyarakat. Karena tidak adanya kewjiban seperti itu, makabisajadi masukan-masukan masyarakat hanya sekedar proses formalitas-formalitas yang secara substansial bukan tidak mungkin masukan mereka tinggal masukan yang tidak akan mempengaruhi hasil akhir dari legislasi Perda.

Di samping itu, bahwa dalam UUP3 2011 ini tampak kuat bercorak prosedur demokrasinya. Hal ini bisa ditelaah secara seksama karena di dalamnya tidak ada satu ketentuan pun yang bersifat imperatif/ yang memaksa agar DPRD dan Kepala Daerah mematuhi prinsip-prinsip demokrasi dalam legislasi Perda. Tidak ada ketentuan sanksi baik administrasi mau pun ketatanegaraan andaikata DPRD atau Kepala Daerah tidak melakukan penyebarluasan Raperda misalnya. Meski tidak disebarluaskan, namun jika Raperda telah dibahas dan disetujui bersama dan kemudian ditetapkan oleh Kepala daerah, maka Raperda sah menjadi Perda. Hal ini dikarenakar dalam UUP3 2011 tidak mengatur tentang komplain publik.

\section{PENUTUP}

Dari seluruh rangkaian hasil penelitian dan pembahasan sebagaimana yang telah dipaparkan di atas, dapat disimpulkan sebagai berikut.

Peraturan Perundang-undangan terkait dengan legislasi Perda yang ada selama ini ada yang sudah dan ada yang tidak/belum memuat dan merumuskan prinsip demokrasi di dalamnya. UUP3 2004 dan UU Pemda 2004 telah memuat prinsip demokrasi, yakni dengan dicantumkannya asas keterbukaan, perihal penyebarluasan Raperda, dan perihal partisipasi masyarakat dalam proses pembentukan Perda. Namun demikian, rumusan tersebut kurang rinci dan tidak besifat imperatif.

Permendagri No. 16 Tahun 2006 tidak mengatur tentang prinsip demokrasi karena Permendagri ini lebih merupakan petunjuk teknis administratifbagi Pemda dalam penyiapan Raperda. Sementara PP No.16/2010 dan Keputusan DPRD Kabupaten Lumajang No. 04 Tahun 2010 yang jelas-jelas merupakan pedoman yuridis yuridis bagi DPRD ternyata sama sekali tidak memuat dan merumuskan prinsip-prinsip demokrasi di dalamnya. Padahal secara hierarki peraturan perundang-undangan, $\mathrm{PP}$ No. 16/2010 dan Peraturan Tatib DPRD berada di bawah UUP3 dan UUPemda yang sebenarnya ia merupakan derivasi lebih lanjut dari kedua UU tersebut.

Terbitnya UUP3 2011 adalah untuk menyempurnakan UU sebelumya sudah mencoba merumuskan secara lebih rinci tentang prinsip demokrasi dalam legislasi Perda. UU ini lebih baik jika dibandingkan dengan UU sebelumnya. Hanya saja di dalamnya belum memuat kesebandingan antara hak masyarakat dan kewajiban DPRD yang besifat timbal baik dalam legislasi Perda.

Berdasarkan hasil temuan, analisis, dan simpulan tersebut di atas, maka sangat patut untuk disarankan sebagai berikut:

a. PP No. 16/2010 untuk segera direvisi dan disesuaikan dengan UUP3 2011 sambil terus disempurnakan dengan memuat prinsip demokrasi di dalamnya.

b. Peraturan Tatib DPRD Kabupaten Lumajang untuk segera direvisi dengan memuat dan merumuskan prinsip-prinsip demokrasi yang lebih rinci sehingga semakin jelas hak dan 
kewajiban masing-masing pihak baik legislatif, eksekutif, maupun masyarakat umum.

c. UUP3 2011 akan lebih baik lagi jika direvisi dengan ditambahi ketentuan tentang kewajiban DPRD dalam legislasi dan ketentuan tentang komplain masyarakat jika ada kerugian yang timbul dari penerapan Perda.

\section{DAFTAR KEPUSTAKAAN}

Moh. Mahfud MD (1999) Pergulatan Politik dan Hukum di Indonesia. Gama Media, Yogyakarta.

SyarifHidayat (2002) Refleksi Realitas Otonomi Daerah dan Tantangan ke Depan. Pustaka Quantum, Jakarta.

Agus Dwiyanto (2002) Reformasi Tata Pemerintahan dan Otonomi Daerah, Ringkasan Eksekutif. Pusat Studi Hukum dan Kebijakan Universitas Gadjah Mada, Yogyakarta.

Buchari Zaenun (1990) Administrasi dan Manajemen Pemerintah Negara Indonesia Menurut Undang-Undang Dasar 1945. Haji Masagung, Jakarta.

Al. Andang L. Binawan (2005) "Merunut Logika Legislasi". Jentera Jurnal Hukum. Edisi 10 Tahun III, Oktober 2005.

Saldi Isra (2004) "Agenda Pembaruan Hukum: Catatan Fungsi Legislasi DPR". Jentera Jurnal Hukum. Edisi 3-Tahun II, November 2004..
Undang-Undang Nomor 10 Tahun 2004 tentang Pembentukan Peraturan Perundangan-undangan

Undang-Undang Nomor 12 Tahun 2011 tentang Pembentukan Peraturan Perundangan-undangan

Undang-Undang Nomor 32 Tahun 2004 tentang Pemerintahan Daerah

Peraturan Menteri Dalam Negeri (Permendagri) Nomor 16 Tahun 2006 tentang Prosedur Penyusunan Produk Hukum Daerah, yang ditetapkan pada tanggal 19 Mei 2006.

Peraturan Pemerintah Nomor 16 Tahun 2010 tentang Pedoman Penyusunan Peraturan Dewan Perwakilan Daerah tentang Tata Tertib Dewan Perwakilan Rakyat Daerah (PP No 16/2010).

Peraturan Tata Tertib Dewan Perwakilan Rakyat Daerah (Peraturan Tatib DPRD) yang dalam hal ini mengambil sampel Peraturan Tatib DPRD Kabupaten Lumajang (Keputusan DPRD Kabupaten Lumajang No. 04 Tahun 2010 tentang Peraturan Tata Tertib Dewan Perwakilan Rakyat Daerah Kabupaten Lumajang).

\section{Biodata Penulis}

Anis Ibrahim. Menyelesaikan S1 Fakultas Hukum Universitas Airlangga Surabaya tahun 1986, S2 Program Pascasarjana Universitas Brawijaya Malang tahun 2000, S3 Program Pascasarjana Universitas Diponegoro Semarang tahun 2008, Jl. Kali Glidik Nomor 4 Lumajang - Jawa Timur. 